\title{
The Study of Literary Criticism on The Well of Loneliness from the Perspective of Toulmin's Argumentation Model
}

\author{
Min $\mathrm{Liu}^{1}$ \\ ${ }^{1}$ School of Foreign Languages, Jiangsu University, Zhenjiang, China \\ Correspondence: Min Liu, School of Foreign Languages, Jiangsu University, Jiangsu, Zhenjiang, China. E-mail: \\ toniliumin@163.com
}

Received: July 4, 2017 Accepted: July 27, 2017 Online Published: September 25, 2017

doi:10.5539/ijel.v7n6p101 URL: http://doi.org/10.5539/ijel.v7n6p101

\begin{abstract}
Literary criticism is a kind of commentary genre, with a certain color of argumentation. Toulmin's model, as an important method of non-formal logic, has played an important role in the analysis of argumentative discourse (Yang, 2004). Therefore, it also provides a new perspective for the study of literary criticism. This paper, on the basis of consummating Toulmin's model, analyzes different specific arguments of The Well of Loneliness, this controversial literary work whether can become a literary classic and widely recognized in different times, combined with literary criticism, and tries to characterize the internal structure of the argumentation, analysis of the dynamic process of argumentation and improvement of the pragmatic strategies of argumentation in a finer way. Thereby, it is more rational to verdict and to verify the rationality and effectiveness of the argumentation. Then suggestions of the construction and perfection of literary criticism can be provided.
\end{abstract}

Keywords: Toulmin's model, literary criticism, The Well of Loneliness, argumentation

\section{Introduction}

\subsection{Background of the Research}

Literary criticism is a kind of commentary genre, with a certain color of argumentation (Terry, 2004). Therefore, literary criticism is the driving force of the progress in literary. Zhou Shuren ( $\mathrm{Lu}$ Xun) also raised the opinion that "only when literary criticism is done well can develop literary creation well" (Chen, 1992, p. 34). One of the important function of literary criticism is to express the critics' awareness and appreciation of the aesthetic value of the literary works, inspiring and helping the readers to raise the level of appreciation, providing correct and meaningful criticism and suggestions for the authors of the literary works. Therefore, it is a great benefit for the readers to clarify the argumentative structure in an effective way to correctly understand the critics' criticism and suggestions. Meanwhile, it is also dramatically meaningful for critics to master the valid literary criticism to write down convincing and understandable commentary articles. However, the study of literary criticism all this time has been limited among the definition, characteristics, function, linguistic features and so on while the research on the structure has been also limited among the components from the macro perspective. On the study of the writing methods in literary criticism, "the writing of literary criticism is not only a comprehensive but also a high level of creative aesthetic activity" (Chai, 2009). On the study of the characteristics of linguistics, "it is helpful to study the intertextual structure of discourse between literary discourse and literary works by referring to the theory of intertextuality, which can help to better sum up the stylistic paradigm of literary commentary discourse and explore its motive and structural regularity" (Zhu, 2011). On the study of the literary commenting language, "literary commentary language to tell the facts, to be accurate, to be scientific" (Yang, 2004). However, the analysis of the structure and process of the argumentation is almost empty. The literary commentary has a certain subjectivity, but the logical argumentative structure of the careful literary criticism and its detailed and clear argument process are of great help to the argumentation and the improvement of the degree of conviction. This essay is a brand-new try that the analysis of literary criticism texts with utilization of Toulmin's model. We can clearly reveal the internal argumentative structure of literary criticism, show the process of argumentation of literary criticism, so as to make the audience analyze the argument structure and method of the whole argument, judge the rationality of their views in a more rational way to get access to more reliable information. But also, it provides new inspiration for the analysis of literary criticism and writing. 


\subsection{Significance of this Research}

This research is very beneficial for literary critics to analyze the whole reasoning structure and methods of the argumentation and to verdict the reasonableness of the arguments aimed at achieving more reliable information in a more rational way. At the same time, this analysis also provides a new enlightenment for the analysis and writing of literary criticism.

\section{Literature Review}

Argumentation is a verbal and social activity of reason aimed at increasing (or decreasing) the acceptability of a controversial standpoint for the listener or reader, by putting forward a constellation of propositions intended to justify (or refute) the standpoint before a rational judge (Eemeren, van Grootendorst, \& Francisca, 1996). Since Aristotle established the Syllogism, the basic argumentation mode which is from the premise to conclusion has constituted the core of the study on Logic (Aristotle, 1984, pp. 100-121). The research on deduction has been continuously extended to the analysis of more common thinking patterns such as induction, analogy, symptom and causality. However, the exploration of the potential common factors hidden in those basic modes is fewer (Driver \& Newton, et al., 2000). With the development of the 20th New Rhetoric, the study of argumentation has re-surged. British philosopher, Stephen Toulmin raised an argumentation model from the perspective of informal logic which achieved the extensive attention and wide recognition. This model has provided a new perspective whether for the study of complicated argumentation phenomena or for the research on argumentation. It also made a great and profound difference. Besides, the study of literary criticism all this time has been limited among the definition, characteristics, function, linguistic features and so on while the research on the structure has been also limited among the components from the macro perspective (David, 1981). The analysis of the structure and process of the argumentation is almost empty. Therefore, it is a brand-new try that the analysis of literary criticism texts with utilization of Toulmin's model.

\section{Theoretical Assumptions}

\subsection{The Introduction of Toulmin's Model}

Toulmin considered that the syllogism argumentation model of the formal logic that the conclusion is from the major and minor premise has a lot of limitations in dealing with the analysis of daily argumentation (McCroskdy, 1965). Thus, he raised an essence logic which matches argumentation practice. How does the validity of arguments depend on the mold in which they are cast and how must we view the validity and form of arguments if we are interested in evaluating them? (Grennan, 1997) These are the questions asked by Toulmin when he turns to the level of single argumentation known as the micro-level. In answering these questions, in 1958, he chose legal argumentation as his example. The mode he introduces to represent the layout of arguments is a procedural one, that is, one in which the various functions of the steps that are successively taken are given due consideration, consisting of claim, warrants, backing, qualifier and rebuttal on the basis of the analogy of jurisprudence. That is the Toulmin's model.

\subsection{The Analytic Framework of Toulmin's Model}

Toulmin pointed out that argumentation begins with data and raises the claim through warrant. Claim, data and warrant are the three basic and essential elements of Toulmin's model. Backing, qualifier and rebuttal are three complementary elements as assistant. In Toulmin's terminology, the standpoint put forward and to be upheld is called the claim (C). How can a claim that has been attacked be defended? One way of defending it is to point to certain facts on which the claim is based that data (D). Then the third step in argumentation consists of providing the justification or warrant (W) for using the data concerned as support for the claim- for the data-claim relationship. The warrant can be expressed by a general statement referring to a rule, principle and so on. In principle, this general statement will have a hypothetical form (if data then claim). The warrant functions as a bridge between the data and the claim. In Toulmin's view the warrant can take different forms. It can be very brief: If $\mathrm{D}$ then $\mathrm{C}$. However, this brief from is based on the assumption that the warrant is a rule without any exceptions, and that the accuracy of the warrant itself is not at issue. The force of the warrant would be weakened if there were exceptions to the rule, in which case conditions of exception or rebuttal(R) would have to be inserted. The claim must then be weakened by means of qualifier (Q). A backing (B) is required if the authority of the warrant is not accepted straight away.

With the development of informal logic, Brockriede and Ehninger interpret Toulmin's model as a rhetorical model, which is reflected in their classification of sorts of argumentation (Brockriede \& Ehninger, 1969). This classification goes back to the Aristotelian tripartition of means of persuasion based on logos, pathos or ethos. The first type they call substantive, the second motivational and the third authoritative. The differences between 
these three forms of argumentation, say Brockriede and Ehninger, must be looked for in the nature of the warrant in Toulmin's model. In a substantive argument, the warrant tells us something about the way in which "the things in the world about us" relate to one another, in a motivational argument, it tells us something about the emotions, values, desires or motives which can make the claim acceptable to the person to whom the argument is addressed, and in an authoritative argument it says something about the reliability of the source from which the data are drawn.

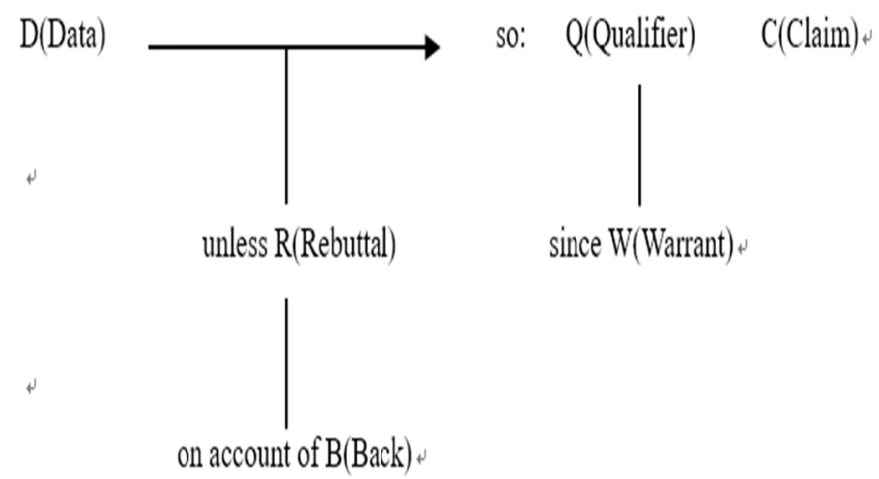

\section{The Argumentation Process of Literary Criticism}

Literary criticism is a kind of commentary genre, with a certain color of argumentation. Literary criticism is the use of literary theory to study, explore, reveal the law of the development of literature to guide the creative work of literary creation. Literary criticism includes poetic commentary, fiction commentary, prose comment, drama commentary, film and television commentary and so on. Literary criticism can be demonstrated through a wide variety of materials (Frank \& Thomas, 1990). Its comments are literary works, including fiction, poetry, prose, drama, painting, film and so on. The purpose of the comment is through the ideological content, creative style, artistic characteristics and other aspects of the discussion, evaluation, commentary, of course, can be sidelined, cited a variety of material argument, so as to improve the level of reading and appreciation.

It is also a theoretical type which focuses on evaluating writers, works, literature and literary trends as the target. Critics express their own knowledge and judgments towards the aesthetic value of the works through writing literary criticism, which can enlighten and help readers improve the level of appreciating the literature. Then correction, meaningful comments and suggestions can be raised.

The Well of Loneliness is written by Radcliffe Hall, which is the first famous masterpiece that wrote lesbians. This work was regarded as "Lesbian Bible". The publishing of this book in 1928 spelled an intense controversy (Hall, 2004).

"On that spring, when Stephen first felt spring like the lingering smoke, she never thought that she would prematurely taste the flavor of frustrated love. When she saw the beloved woman lying in the arms of a man, he was kissing the woman rudely. A child's panic and anger turned into a broken flowerpot in Stephen's hands, smashing the man's body. Blood flowed out from his pale face, but the mental suffering of a person who has sexual perversion drifting lonely in the heterosexual world has not been suppressed. She tried to escape until the fate caught her."

This is the first description of lesbian love in The Well of Loneliness. In 1928, shortly after its publishing, the London court judged its content "obscene" and it shall be destroyed immediately. Radcliffe Hall shouted outside the court: "I protest, strongly protest!" which also did not change the determination of the judge. Until nearly 80 years later, the novel was to get lifted and to be brought to light. This extraordinary novel of passion proved to the whole world that lesbian love is not dirty and ugly. It was stereotypes and recalcitrance that designated a cage for lesbian love. This novel describes Stephan's first half life which shows the unyielding struggle.

This book has not been accepted for a very long time although there were more than forty celebrities such as Shaw, Forster, and Eliot, Woolf couple and Hemingway and Dreiser supporting this novel. This research will choose a literary criticism by Liu Jinjuan on this book and analyze how this literary criticism evaluate and argue for the right of lesbians. 
In the beginning of 20th century in Europe, in various mechanisms which were defending the ideological, there was no space for the lesbians. Heterosexuality was preached in school, church, marriage and family while homosexuality is taboo and cannot be spoken. Therefore, homosexuals should firstly face the confusion of who they are before facing the giant challenge by various mechanisms. This novel is no doubt a denouncement and challenge to the tradition and values of heterosexuality. What Hall's The Well of Loneliness wish is the tolerance and acceptability of homosexuality from the whole world.

This article will take "the Speak for the Homosexual-An Analysis of Morris and The Well of Loneliness" to analyze the argumentative structure and process of literary criticism in details (Liu, 2012). In this critical article, this author mentions the key argument in the opening of this literary criticism, that is the claim of the model, which is that lesbians' right to survive and to pursue the happiness should be stuck up for. And then, several arguments are followed to strengthen this claim such as the confusion of the body and the desire of the body. The author concludes the arguments with a two-tiered structure. The relevant arguments are integrated as follows:

To sum up, this literary criticism's argumentation process is showed in the following.

(1).

Claim: Lesbians' right to survive and to pursue the happiness should be stuck up for.

(What have you got to go on?)

Data: Lesbians are the same as heterosexuals.

(How do you get there?)

Warrant: They have the same desire of the body as heterosexuals. (Is that always the case?)

Rebuttal: No, but it essentially is if the different ways of having sex are taken into account or the topic of talking about sex is a taboo.

Qualifier: True: it is only essentially so.

Backing: Lesbians are bound together because of love should not be considered as $\sin$ in the eyes of God.

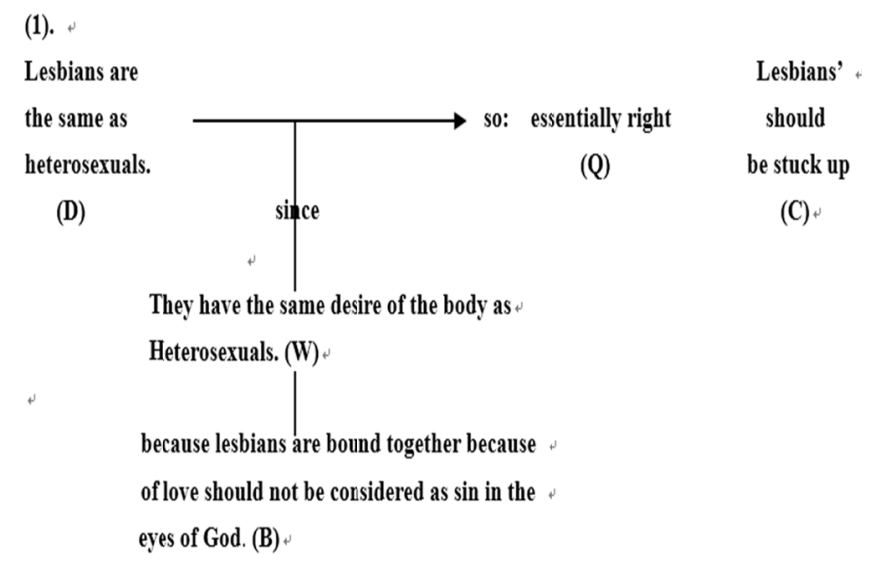

(2).

Claim: Lesbians should be tolerant and respected.

(What have you got to go on?)

Data: Lesbians have the severer confusion of identity and greater challenge to the world.

(How do you get there?)

Warrant: Their physiological gender cannot match their psychological gender congenitally and posteriorly.

(Is that always the case?)

Rebuttal: No, but it generally is if homosexuality is a bit more acceptable as time goes, they would not shoulder much more suffering of the confusion of identity and challenge.

Qualifier: True: it is almost certainly so. 
Backing: Lesbians are bound together because of love should not be considered as $\sin$ in the eyes of God.

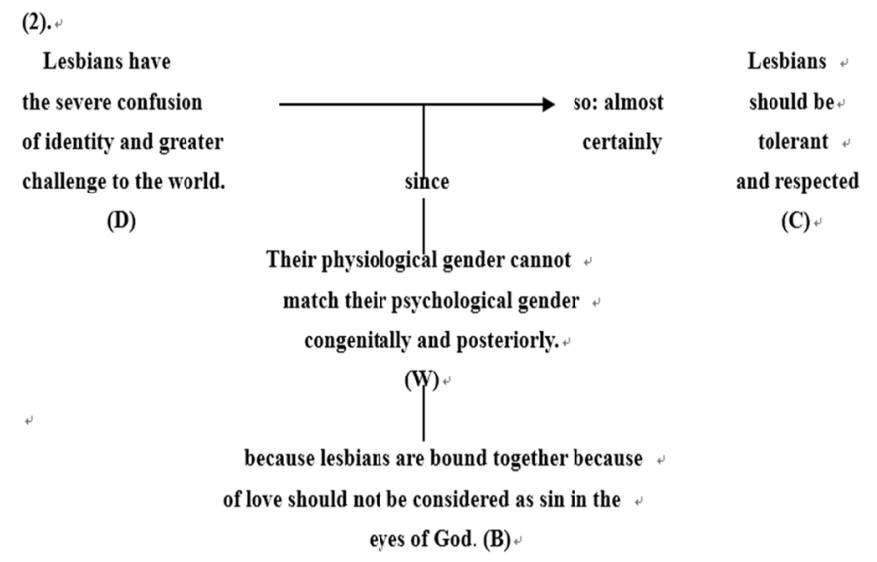

In this case, the Toulmin's model simplifies the argument discourse in the form of outline, reveals the argumentative framework of literary criticism, excavates the inner logical structure and reasoning process and reveals the relationship between the constitutive relations. The whole commentary arguments and the structure are clear, justified and valid. As Toulmin said, "in the various studies, explorations, and decisions that people have made, what are the "reason" that we use in the end? And how the "functional differences" of "reason" in different areas will affect how we evaluate the arguments and beliefs in different areas?" (Toulmin, 2015), everything mentioned above is achieved in the analysis in this paper, and the analysis of the functional differences in the reasons for literary criticism will constitute an important aspect of the next step.

\section{Argument Strategy in Literary Criticism}

In Toulmin's model, the fact is not conclusive. The proof of the facts directly depends on the author's creativity and imagination, so called "artistic proof (proof)", that is, Aristotle mentioned that "the probable proof belonging to the art itself" in Rhetoric (Aristotle, 1984). Ehninger and Brockriede argued that the use of artifacts in rhetoric arguments can be divided into rational arguments, authoritative arguments, emotional arguments. In the view of Toulmin, the argument will seek validity, but this validity refers not only to the logical level, but also to the substantive level of validity. In the actual argumentation, the argumentation is not only to eliminate the controversy. More importantly, the purpose is rhetoric, that is to persuade the audience, access to the audience obedience and support (Chritopher \& Tindale, 1999). "The rhetorical argumentation argues that the rationality of the argument is linked to certain standards and morality, arguing that the argumentation is sufficient to take account of the specific circumstances of the audience, including the value orientation, and that the argument is acceptable as long as they can win the recognition" (Fan, 2003).

Throughout the persuasion process, the use of arguments is particularly important. In support of the reasoning, the use of the arguments covers three types of rhetoric. Next, the language of the literary criticism will be analyzed by the rhetorical model to explore the argumentative structure of literary criticism and to explain the artistic connection between data and claim (Leavis, 1937).

\subsection{Rational Argument}

Rationality has always been the greatest characteristic of mankind which is different from other animals and the most basic characteristic of mankind. The rational argument stresses that the truth of facts or the truth is that people believe that what is true (Hitchcock, 2005). Thus, rational argumentation usually uses facts, examples and intellectual views, as well as induction, comparison, causality and other means of logical argument to persuade the audience to accept their views (Jonsenm \& Toulmin, 1988). The intellectual view is directly related to the knowledge structure and the cognitive ability, and it can be seen that different people have different potential differences on the rational arguments.

In this critic article, in the early 20th century, Europe, in the defense of ideology of the various mechanisms, there is no homosexuality of the school, church, marriage, the family is preached are heterosexual. Homosexuality is taboo, cannot speak. Therefore, Homosexuals are confronted with what people are confronted with before the great challenges of syllable systems. With the model, we can further dig deeper into the argument 
that lesbians are more confused about identity and the world has greater challenges, and therefore further stressed the argument that "lesbians should be more tolerant and respect." The rational argument is the main part of this literary criticism.

\subsection{Emotional Argument}

Aristotle speaks of the role of emotional argument in Rhetoric: "When the audience's emotions are moved by the speaker, the speaker can use the audience's mind to be persuasive because we have different judgments when we are in different moods such as in sorrow or joy, kindness or hatred." (Aristotle, 1997) From this point of view, the emotional argument is no less than rational argument. Emotional arguments often use the reader's indignation, compassion, disappointment and anxiety and other personal emotional factors to persuade.

In this critical article, the heroine of The Well of Loneliness, Stephen's pain, comes from the shackles of religion and secular prejudice, and Stephen accepts Christ as a believer, and now finds himself a sinner in the sight of God, and her feelings fall into the abyss. She does not understand where she is wrong in the end, which will be subject to God's punishment, like Cain whom God was marked on the forehead. She was treated as "morally leprosy". She felt ashamed and frightened about her own "survival mystery" so that her mother felt "nauseous", but she could not change her own homosexual tendencies. This part inspires the readers' sympathy heart by describing the lesbian's confusion about self-identity in details.

\subsection{Authoritative Argument}

The authoritative argument argues through the three excellent qualities of the "knowledge, virtue and goodwill" of the arguer (Jin \& Wang, 2015). Because of the knowledge, the arguer can put forward the correct view; because of virtue and goodwill, the arguer can share the views which they know with the audience. The power of authoritative arguments depends on the psychological role of the audience, the higher the degree of trust in the audience, the greater the likelihood of accepting his or her speech. Aristotle said: "In fact, it basically can be said that the speaker's character has the most important persuasive force."

The literary commentary mentioned "before the Bible listed in this article on homosexual taboos can also be understood that it is God is in the punishment of fornication rather than the true love between each gay. Gay is not a group of men and women who only have the sexual desire. They still love deeply, love bravely, and they also can sacrifice their own life to the person they love. And the combination of homosexuality because of love should not be the sins of God's eyes." Here the author starts the argumentation from the authority-God. Authoritative remarks can convince the readers and the argument doesn't have any doubt.

In the above three arguments, rational argument is to solve the logical problem-feasibility; authoritative argument is to resolve the psychological factors of the audience-credibility; emotional argument is to resolve the audience's emotional bias-acceptability. Among them, reason is the basis and feasibility and acceptability are the most important factors affecting the success of argumentation.

\section{Conclusions and Implications}

It has been past for eight or nine decades since the novel has been finished writing. People's acknowledgment of homosexuality has turned for three times. The first time is making homosexuals experience the transition from sinner on religious sense and criminal on legitimate sense to the patient. The second time is the transition from the pathology of the body or the soul to the normal situation. The third time is that homosexuality is a totally different lifestyle and it has achieved legal status in many countries. In those three transitions, argumentation by a lot of literary authors made a great difference.

Toulmin's model describes the structure of reasoning and process and also provides a new perspective of analyzing and writing literary criticism. From this research, some implications are as follow.

Firstly, controversy happens in that the acceptability of the book or the related topic is doubted. Therefore, it is very important to conclude a concise opinion in a literary criticism (Kuhn, 1993). The type and ways of expression of those arguments directly decide the structure and ways of argumentation. Meanwhile, those arguments need warrants and backing to support the argumentation.

Secondly, it is general that argumentative speech act is a dispersed and single group. This group should be connected with the arguments which the group is supported by some certain methods such as internal logic deduction. Thereby a rigorous entirety can be formed, which is just the meaning of Toulmin's model. Therefore, what role that each component plays in the argumentation structure is? What are the relations between the components? What conclusions can be attained through the book? Literary critics should clearly know about these points. 
At last, when literary critics write the criticism on the books, they should pay more attention to the readers. They need to give more importance to rhetoric. Those comments should make readers consider as the reply to the doubts or refutation of readers' heart.

However, literary criticism has certain subjectivity which cannot be avoided. Literary critics should try to hold more rational attitudes toward the related books. Then, the controversial topics written by authors can be more acceptable and acknowledged by more and more readers.

\section{References}

Aristotle. (1984). Rhetoric (pp. 100-121). New York: Modern Library.

Bailey \& Quentin. (2002). Heroes and Homosexuals: Education and Empire in E.M. Foster. Twentieth-Century Literature, 48(3), 324-347. https://doi.org/10.2307/3176031

Brockriede, W., \& Douglas, E. (1969). Toulmin on Argument: An Interpretation and Application. Quarterly Journal of Speech, 4, 44-53. https://doi.org/10.1080/00335636009382390

Chai, Y. (2009). On the Writing of Literary Criticism. Journal of Suihua University (Philosophy and Social Sciences Edition), 2, 128-130.

Chen, A. Y. (1992). The Role of Literary Criticism in the Supplement of Professional Newspaper (pp. 9, 34-35). Henan Post and Telegraph Newspaper Press.

Chritopher, W. T. (1999). Acts of Arguing: A Rhetorical Model of Argument. Albany: State University of New York. https://doi.org/10.1023/A:1011264731135

Driver, R., N. et al. (2000). Establishing the Norms of Scientific Argumentation in Classrooms. Science Education, $84(3)$,

287-313. https://doi.org/10.1002/(SICI)1098-237X(200005)84:3<287::AID-SCE1>3.0.CO;2-A

Eemeren, F. H., van Grootendorst, R., \& Francisca, S H., (1996). Fundamentals of Argumentation Theory: A Hand book of Historical Backgrounds and Contemporary Developments. New Jersey: Lawrence Erlbaum Associates, Inc., Publishers.

Eemeren, F. H., van Grootendorst, R., \& Snoeck, H. (1996). Fundamentals of Argumentation Theory. Mahwah, NJ: Erlbaum.

Emeeren, F. H., van Grootendorst, R., \& Kruiger, T. (1984). The Study of Argumentation. New York: Irvington.

Grennan, W. (1997). Informal Logic: Issues and Techniques. [S.1.]: Montreal, Quebec: McGill-Queen's University Press.

Hall, L. (2004). The Well of Loneliness (L. Zhang, \& Y. Zhan trans.). Beijing: Culture Art Press.

Hastings, A. C. (1962). A Reforming of the Models of Reasoning in Argumentation, in Dissertation, Evanston IL, Northwestern University.

Hitchcock, D. (2005). Good Reasoning on the Toulmin Model. Argumentation, 19(3). https://doi.org/10.1007/978-3-319-53562-3_23

Jin, L., \& Wang, M. (2015). The Study of News Comment from Perspective of Toulmin's Argumentation Model (pp. 81-89). Zhejiang Social Sciences.

Jonsenm, \& Toulmin. (1988). The Abuse of Casuistry: A History of Moral Reasoning. Berkeley: University of California Press.

Kuhn, D. (1993). Science as Argument: Implications for Teaching and Learning Scientific Thinking. Science Education, 84(3), 287-313. https://doi.org/10.1002/sce.3730770306

Leavis, F. R. (1937). Literary Criticism and Philosophy. Scrutiny, 6, 60-61.

Lentricchia, F., \& Mclaughlin, T. (1990). Critical Terms for Literary Study. Chicago: The University of Chicago Press.

Liu, J. J. (2012). Speak for the Homosexual-An Analysis of Morris and The Well of Loneliness. Masterpieces Review, 114-116.

Lodge, D. (1981). 20th Century Literary Criticism. New York.

McCroskdy, J. C. (1965). Toulmin and the Basic Course. Speech Teacher, 14, 91-100. https://doi.org/10.1080/03634526509377426 
Terry, E. (2004). Literary Theory: An Introduction (2nd ed.). Beijing: Foreign Language Teaching and Research Press.

Toulmin, S. (2001). Return to Reason. Cambridge, MA: Harvard University Press.

Toulmin, S. (2003). The Uses of Argument. Cambridge: Cambridge University Press. https://doi.org/10.1017/CBO9780511840005

Yang, K. X. (2004). Criticism on the Language of Literary Criticism-Query on the Message of the Editor of the People's Literature. Journal of Chongqing Three Gorges University, 6, 41-43.

Zhu, K. Y. (2011). A Study on the Interactive Relationship between Meta-discourse and Literary Criticism. Contemporary Rhetoric, 7, 1-10.

\section{Copyrights}

Copyright for this article is retained by the author(s), with first publication rights granted to the journal.

This is an open-access article distributed under the terms and conditions of the Creative Commons Attribution license (http://creativecommons.org/licenses/by/4.0/). 